\title{
A new era in Russian gas market: The diminishing role of Gazprom
}

\author{
Volkan Özdemir* \\ EPPEN (Institute for Energy Markets and Policies), G:3 No: 24 P.K., 06530, Bilkent-2 Ankara, Turkey
}

\section{Sohbet Karbuz}

Mediterranean Energy Observation (OME), 32 Bis Boulevard Haussmann 75009, Paris, France

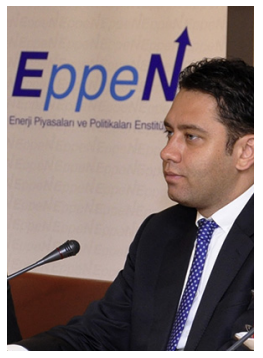

\section{Introduction}

After the breakup of the Soviet Union, Russia's natural gas sector developed in the opposite way to the country's oil sector. The Russian oil sector was largely decentralized and there was strong competition mainly between the private oil firms in the 1990s and the first half of 2000s, which prevented any firm from dominating the market. This started to change mainly after the state oil company Rosneft acquired TNK-BP in 2013. The deal enabled Rosneft to control nearly half of Russia's total oil output and hence obtain a dominant position in the sector. As a result, the oil sector is progressively grouped around an emerging national champion. ${ }^{1}$

\footnotetext{
* Corresponding author.

E-mail addresses: ozdemirvolkan@gmail.com (V. Özdemir), sohbet.karbuz@ome.org (S. Karbuz)

1 Other than Rosneft, there are also several Russian oil companies with significant production such as the private company, Lukoil and the state owned Gazpromneft and Surgutneftegaz.
}

The Russian gas industry is in a transition, which can be characterized as modest decentralization. While its gas production continues to decline and competition on the Russian market intensifies, Gazprom will have to adapt to changing conditions. Non-Gazprom producers are increasing their share in total gas production. Major structural reforms may make the market structure in gas and oil sectors more and more similar in the longer term. Although liberalization is partly achieved for LNG exports, the pressure is now building on breaking Gazprom's pipeline gas monopoly. On the other hand, Gazprom is currently facing several challenges on the European market. Gazprom might unbundle transmission sector along with others. All these will, sooner or later, prepare the demise of Gazprom monopoly.

The natural gas sector, however, has remained highly centralized under Gazprom a vertically integrated state behemoth. The Gazprom model resulting from the reforms that took place in the 1990 s endorsed a monopolistic structure in the transmission and export segments and in the production to a lesser extent. However, this model is now being called into question as a result of the developments in the domestic and international gas markets, particularly in the European gas market that is the core destination for Russian gas exports. Two main factors have caused Russian decision makers to reconsider the country's gas export policy. The first factor is the high possibility of a demand driven market and the North American shale gas revolution. The second factor is about finding a way to deal with the EU's desire to create a competitive and integrated European gas market as outlined in the EU 3rd energy package in 2009. In addition, starting from December 2013 the export monopoly of Gazprom was abolished in LNG exports. It is possible that the diverse group of non-Gazprom producers ${ }^{2}$ will account for more than one third of Russian production, and over half of all domestic gas sales in the future [1]. Such a situation will not only have ramifications on Russian gas exports but could also break Gazprom's monopoly in pipeline gas exports.

The aim of this article is to address the question of whether the monopoly of Gazprom is diminishing. In order to answer that question the article looks at the issue from several angles. First, an analysis is given concerning the evolution of Russian gas market from past to present with particular emphasis on the role of non-Gazprom producers. Second, the main reasons for the market liberalization that caused the decline of Gazprom's share in Russian gas production are investigated. Furthermore, the increasing weight of non-Gazprom gas producers in the market is also considered in terms of their

\footnotetext{
2 The term "non-Gazprom producers" is used rather than "independent producers" in order to describe the increasing role of gas companies in Russia.
} 
relations with the Kremlin. Thirdly, an overview is presented of the possible impacts of the structural changes taking place in domestic market on Russian gas exports and discussed the role of export infrastructure. The presentation of the evolving competition in the Russian gas industry provides for a comparison with the oil sector. Finally, the alternative options to reduce Gazprom's monopoly are discussed.

\section{The Russian gas market and the role OF non-Gazprom producers}

Until recently, the Russian domestic gas market was characterized by the lack of competition because of the highly centralized Gazprom model. The state-controlled Gazprom has had a monopoly on the main segments of the gas chain, including the transmission network. Gazprom's daughter transmission company, MRG, usually limited access to the networks due to either available capacities or the different calorific value of the gas produced by other producers [2]. The most significant restriction of competition lay in the tariff structures and access regulation by the Russian authorities. In recent years the Federal Antimonopoly Service played a significant role in pressuring Gazprom to open up norms for access to networks with an aim of bringing competition to the market. The Federal Tariff Service, on the other hand, regulates gas prices in the domestic market. Historically, prices have been very low, even at times below the cost of production. For example, when in 2006 the Putin government set a target of gas prices reaching European levels by 2011, the domestic gas prices were very low [3]. Since then a concerted effort has been made to increase the domestic gas price towards the European netback export prices although the first target of reaching this policy by 2011 failed. Nevertheless, the increase in regulated gas prices in the past decade ${ }^{3}$ and the subsequent improvements in the economics of gas sales in Russia have attracted a number of companies to enter in the domestic market. NonGazprom producers have enjoyed a tax incentive in Russia since late 2011 after an amendment in the tax law. According to this law, the Mineral Extraction Tax was set for the companies that have a transport system

\footnotetext{
3 If the domestic gas prices had been increased in line with the average inflation rate then domestic prices would have reached European gas market prices in a decade. As Henderson's study explained the increase in domestic gas prices had to stay at minimal levels while the consumer price index was dramatically increasing in Russia after the 2008 world economic crisis. The inflation rate was $14.1 \%$ in 2008 and $11.7 \%$ in 2009 (http: / / www.inflation.eu/inflation-rates/russia/historic-inflation/cpi-inflation-russia.aspx).
}

(Gazprom) as 509 rubles for 2012, 602 rubles for 2013 and 700 rubles for 2014 per $1000 \mathrm{cu}$ bic meters of gas extracted. ${ }^{4}$ The same tax burden, however, is much lower for nonGazprom producers with a reduced coefficient of the established rate, which is nearly half of that of Gazprom [4].

In addition, non-Gazprom producers have started to exploit the opportunity to sell their gas in the domestic market at negotiated prices, which seems quite competitive relative to Gazprom's regulated price. In 2012, the share of end customer sales of the total sales of the two big non-Gazprom producers, namely Novatek and Rosneft amounted to 62\% [5]. If energy efficiency gains are achieved, especially in the power and industrial sector, the demand for gas in domestic market is likely to be lower than expected. This could make Russian gas sector more competitive since the non-Gazprom producers, benefiting from the lower marginal cost of production, already have sold gas profitably at prices below the regulated tariff charge [6].

Non-Gazprom producers' right to form long-term contracts with end consumers is the clearest evidence of the evolution in the Russian gas market. The first signs of significant competition between domestic suppliers actually emerged in 2009 when Novatek signed a contract to supply Inter RAO, a Russian electricity trader, and its generating subsidiary OGK-1 with $65 \mathrm{bcm}$ of gas from 2010 to 2015. In 2012, Rosneft also signed a gas contract with the state-controlled power company Inter RAO to supply up to $35 \mathrm{bcm}$ of gas annually from 2016 to 2035 [7]. It is clear that a new strategy in gas industry, which pushes non-Gazprom producers to enlarge their activities, is the main reason for the reduction in Gazprom's share. Moreover, the domestic gas market in Russia has tightened in recent years. Gas consumption in 2013 was $456 \mathrm{bcm}$. For several reasons, ${ }^{5}$ the high growth rates of early 2000 s are unlikely to be repeated in the future. The expectation for 2020 is around $500 \mathrm{bcm}$ and for 2030 close to $540 \mathrm{bcm}$ [8]. Given the potential for excess gas supply in the Russian market in the next decade combined with the increasing competitive threat from nonGazprom producers, it seems that Gazprom may lose more ground in the domestic market, even if it is still the largest supplier of gas to the domestic market, accounting for approximately $70 \%$ of total gas supplies [9].

\footnotetext{
$1 \$=32$ rubles in 2012, 33 rubles in 2013 and 40 rubles in 2014.

5 These include economic slowdown, the Government's plans and investments to increase efficiency in gas consumption and the impact of political developments.
}

\section{The decline in the Gazprom share of Russian gas production}

The slowdown of growth in both the domestic market and Russia's export markets has caused Russia to limit production since 2008. Although Gazprom reduced its activities, non-Gazprom producers have continued to invest, albeit at a reduced pace given the current economic and financial conditions, and increased their production. The share of non-Gazprom producers in the total Russian gas production has continued to grow. The two biggest non-Gazprom producers, Novatek and Rosneft, deserve special attention (see Table 1).

The largest of the non-Gazprom gas producers, Novatek, has more than doubled its production since 2007, reaching $62 \mathrm{bcm}$ in 2013 [10]. In 2011, Gazprom totally lost its control in Novatek [11]. ${ }^{6}$ In recent years Novatek acquired gas assets and fields with remarkable gas reserves such as Sever Energiya and Sibneftegaz that were subject to swap deals between the company and Rosneft. ${ }^{7}$ Most importantly, it was able to secure incentives from the Russian Government for the development of the Yamal LNG Project. Novatek's success is largely attributed to its influential owners, namely Genady Timchenko, the largest shareholder and owner of Gunvor, an oil trade company, and Leonid Mihailson, the CEO of Gunvor, who have special relationships with political circles in the Kremlin. This claim is supported by the fact that after the sanctions, Novatek did not find any difficulty in obtaining 150 billion rubles from the Government for its Yamal LNG project under the National Wealth Fund, which is supposed to be spent on the national pension system [12].

Increasing competition between two State companies, Rosneft and Gazprom, is a specific characteristic of the institutional reform in the Russian hydrocarbon sector since the presence of competitors enables the Kremlin to reduce the information asymmetry in its relations with Gazprom, which has long been seen as a State within the State [1]. The aggressive entry of Rosneft into the gas sector constitutes a challenge for Gazprom's traditional domination of the political scene of the country. Like Novatek, a large part of Rosneft's success is attributed to the company's CEO, Mr. Igor Sechin, who is a close

\footnotetext{
${ }^{6}$ Gazprombank sold its $9.4 \%$ share in Novatek and later French Total became shareholder with an option to upgrade its stake up to $19 \%$. Since then the company has become a significant player in the market.

7 Voice of Russia, Russian gas company ITERA to own 99.9\% stake in Sibneftegaz, 24 January 2014. Available at: http://voiceofrussia.com/news/2014_01_24/ Russian-gas-company-Itera-to-own-99-9-stake-in-Sibneftegaz-0828/.
} 
Table 1

Russian gas production and reserves by the companies.

\begin{tabular}{llllll}
\hline & $\begin{array}{l}\text { Gas production } \\
\text { 2010, bcm }\end{array}$ & $\begin{array}{l}\text { Gas production } \\
2011, \mathrm{bcm}\end{array}$ & $\begin{array}{l}\text { Gas production } \\
2012, \mathrm{bcm}\end{array}$ & $\begin{array}{l}\text { Gas production } \\
2013 \mathrm{bcm}\end{array}$ & $\begin{array}{l}\text { Gas reserves } \\
\text { tcm in 2014 }\end{array}$ \\
\hline Russia, total & 665 & 687 & 671 & 668 & 47 \\
Gazprom & 513 & 519 & 487 & 480 & 35 \\
Novatek & 38 & 53 & 57 & 62 & 1.75 \\
Rosneft & 12 & 13 & 26 & 42 & 3 \\
Others & 102 & 102 & 101 & 84 & \\
\hline
\end{tabular}

Source: Numbers are derived from companies' web sites.

friend of Vladimir Putin from the KGB and St. Petersburg years. ${ }^{8}$

In 2011, Rosneft had relatively insignificant activity in the Russian gas market with a production of $13.4 \mathrm{bcm}$, mostly in the form of associated gas from the company's mega oil fields (such as Vankor). However, Rosneft took a strategic step in 2012 by forming a joint venture with Itera, an independent. It further enhanced its position in 2013 through the finalization of its purchase of TNK-BP. In fact, Rosneft acquired not only Russia's third largest oil producer but also a company that has significant gas production growth ambitions of its own, due largely to its Rospan subsidiary in West Siberia. Overall, Rosneft appears to have the resource base and marketing capability to rapidly increase its sales in the domestic market.

Russia produced $668 \mathrm{bcm}$ of natural gas in 2013. Gazprom is by far the largest producer, with $480 \mathrm{bcm}$ [13]. For the first time in 2013, the combined production of Novatek and Rosneft has exceeded $100 \mathrm{bcm}(62 \mathrm{bcm}$ and $42 \mathrm{bcm}$, respectively) [14]. Both Novatek and Rosneft are targeting at least $100 \mathrm{bcm}$ of production by 2020 . These targets seem ambitious under current market conditions, but according to some estimates they will reach, and even exceed, their targets: Novatek from $62.2 \mathrm{bcm}$ in 2013 to $115-120 \mathrm{bcm}$ in 2020, and Rosneft from $42 \mathrm{bcm}$ in 2013 to $100 \mathrm{bcm}$ in 2020 [15].

According to the Russian Energy Strategy up to 2030 , gas production in Russia will reach $885-940$ bcm by 2030 [16]. The Russian Academy of Sciences expects a lower production level by 2030 (772 bcm) under its baseline scenario [17]. This means that unless Gazprom substantially increases its future production levels, the share of non-Gazprom producers in the total Russian gas production will likely increase.

\footnotetext{
8 Igor Sechin, who served as the deputy prime minister responsible for Fuel-Energy Complex long years, is considered by many as the most powerful man in Russia after Vladimir Putin. He is the president of Rosneftegaz which has the largest share in Rosneft and owner of the different energy assets in Russia.
}

\section{Non-Gazprom producers eye for breaking Gazprom export monopoly}

The North American shale gas revolution, competition from rival infrastructure projects and increasing number of global LNG suppliers combined with massive changes in the European energy market where demand outlook for gas is blurry ${ }^{9}$ have put pressure on Russia to revisit its strategy or form a new strategy that can overcome these challenges and ensure Russia's continued role as the leading global gas exporter.

In 2013, Russia exported $196 \mathrm{bcm}$ natural gas, most of which to Europe (138 bcm) [18]. Exports to Europe have significantly decreased since 2008 ( $158 \mathrm{bcm}$ in 2008) due to the considerable decline in the demand for gas in Europe in the past few years as a result of the worsening economic situation as well as weather conditions. According to Eurogas estimates, European gas demand in 2014 was 11\% lower than in 2013 [19]. 2014 was an exceptionally warm year with record high temperatures. In addition, low coal and carbon dioxide prices combined with increased amount of electricity production using renewable energy sources amplified the overall decline in gas demand. Nevertheless, the share of imports from Russia has been stable though Russian imports dropped in volume terms. This is partly due to the long term contractual obligations and changing dynamics in the LNG markets after the Fukushima incident in Japan which has caused the average utilization rate of the EU's LNG regasification capacity to sink to as low as $25 \%$ [20].

Gazprom has managed to preserve the key components of its contract terms (long-term minimum take or pay obligations with prices essentially linked to oil products). By making small concessions, it strived to endure the

\footnotetext{
9 This process has accelerated since the world economic crisis of 2008 and resulted in a drop in the amounts of gas imported from Russia. The legal restructuring of the European market goes hand in hand with the process of a new form of hub-based pricing mechanism, which has the potential of significantly reducing the weight of oil price indexation in the continent. Moreover, the European gas demand remains weak and the outlook for future is still uncertain since the role of natural gas in the European energy and electricity mix is blurry.
}

changing realities of the European market, in which the price of the gas started to be delinked from the price of oil [21].

Gazprom has been facing serious criticisms centered on the price renegotiations and even arbitration cases from its biggest clients in Europe. Gazprom strategy may be successful in the short term but with the new wave of global LNG supply and unconventional gas, these tactics may not be enough. For Russia, there will be no option but to adapt to the changing realities. Since Gazprom is not willing to adapt to these changes, Russian decision-makers encourage nonGazprom producers that are eager to benefit from profitable export markets.

The former Polish Prime Minister Donald Tusk argued that Europe should not prolong the contracts with Gazprom that will expire in 2020s [22]. He offered to form a European Energy Union. After the events in Crimea, German premier Angela Merkel also supported this initiative. Tusk has become the President of the European Council in December 2014 and his Energy Union vision was put forward by the European Commission in early 2015.

Following a more compromising way with European actors will be helpful for Russia in terms of not only securing exports but also solving the big infrastructure problems with Europe. To achieve this, in addition to Gazprom, Russia needs additional instruments and players in export markets.

In recent years, Moscow has come under increasing pressure from independents led by Rosneft and Novatek to revise the country's gas market. Gazprom proposed to purchase LNG from the domestic players and sell it on abroad as its own gas. However, this formula did not suit non-Gazprom producers. Non-Gazprom producers also call for the government to change the country's gas transport tariff and the phasing out of crosssubsidization while Gazprom urges the government to get the right to discount prices as its competitors do. Rosneft and Novatek have been trying to challenge this and hope to win the right to export their gas. In fact, their lobby to abolish the export monopoly of Gazprom, or de-Gazpromisation of Russian gas exports, was partially successful. In October 2013, the government approved amendments to the law to liberalize LNG exports. Putin approved the law on 1 December 2013. The new regulations limit future entrants into the Russian LNG market with exports being permitted only from three types of project: those already holding LNG production licenses before 2013; state companies if they produce LNG from offshore fields; and projects operating under production sharing agreements. Currently only Novatek with the Yamal LNG project and Rosneft with the Sakhalin-1 project gain from the amendment. 


\begin{tabular}{|c|c|c|c|c|}
\hline & Total exports (bcm) & Exports to Europe $(\mathrm{bcm})$ & Exports to CIS countries (bcm) & $\begin{array}{l}\text { Average price } \\
\$ \text { per } 1000 \mathrm{~m}^{3}\end{array}$ \\
\hline 2007 & 191.9 & 154.4 & 37.5 & 233.66 \\
\hline 2008 & 195.4 & 158.4 & 37 & 353.69 \\
\hline 2009 & 168.4 & 120.5 & 47.9 & 249.27 \\
\hline 2010 & 177.8 & 107.4 & 70.4 & 268.48 \\
\hline 2011 & 189.7 & 117.2 & 72.5 & 338.88 \\
\hline 2012 & 178.7 & 112.7 & 66 & 348.33 \\
\hline 2013 & 196.4 & 138 & 58.4 & 342.29 \\
\hline
\end{tabular}

Source: Central Bank of Russian Federation.

This can be interpreted as the first sign of demonopolization of exports (see Table 2).

The rising competition in the Russian domestic market and export ambitions of Novatek and Rosneft should be viewed in light of the Kremlin's new understanding of the Russian Energy Policy due to the changing dynamics in the gas industry. The balance of power in the gas sector is shifting from once overpowered Gazprom to Novatek and Rosneft. Although Gazprom still keeps its monopoly over the existing pipelines, both companies will most likely continue to lobby to end Gazprom's monopoly of pipeline exports. The chairman of Rosneft, Igor Sechin, has already proposed that Moscow should grant the right to export gas via the pipeline system to other gas producers [23]. The right to export gas by pipeline will probably be put forward in the future. However, if and when this happens, liberalization will rather unlikely to bring a real competition between Gazprom and independent producers, in terms of both volume and price due to the direct and indirect influence of the Kremlin on the main actors in the western markets. Whatever the form, the competition between the main players will advance as much and as long as it aligns with the interests of Kremlin.

According to the Federal Custom Regulations, Gazprom currently does not pay an export duty for the supply of gas imported from Azerbaijan and Central Asia; rather it transports this gas as an international transit. The big monetary loss in the Federal Budget due to tax exemption could be remedied by non-Gazprom producers supplying the amount of gas. Russia, in turn, would benefit from the foreign trade surplus and an increased budget revenue [5].

So far, it is unclear how exactly the Ministry of Energy is going to coordinate LNG exports and protect Gazprom's market niche in Europe; however, it is obvious that there will be no legal ban on LNG exports to Europe by non-Gazprom producers although the main target is Asian markets. ${ }^{10}$ Despite the

\footnotetext{
10 Just a few days before the approval of the legislation, Novatek announced a 25-year contract with the Spanish Gas Natural Fenosa for an LNG supply of 3. $2 \mathrm{bcm} / \mathrm{yr}$.
}

numerous technical and economic problems, LNG in Russia will grow, and Asia may become one of the leading pillars in the gas export strategy of the country.

According to the Energy Strategy of Russia to 2030 , Russia will export $340-360 \mathrm{bcm}$ of natural gas by 2030, and the share of LNG in exports will reach $15 \%$. The Ministry of Energy, on the other hand, targets a $20 \%$ share for LNG by $2030 .^{11}$ However, Russia can only begin delivering large-scale LNG supplies after 2018. After 2025, Russia may have a considerable potential to increase its influence on the market although the current intention to achieve $20 \%$ of the global LNG market is highly unrealistic when its current share of $3.6 \%$ and sanctions are taken into consideration [24].

\section{The importance of the future role of the gas export infrastructure} demand' and to avoid transit risks, Russia aims to diversify its export infrastructure developing ambitious pipeline projects and investing in LNG. Russian policy makers also consider these projects as an instrument rather than an end in itself to achieve the planned reform in the Russian gas industry described above.

In May 2014, Gazprom and CNPC signed a 30-year natural gas supply contract. Gas will be delivered via the $4000 \mathrm{~km}$-long Power of Siberia trunk line encompassing the Yakutia and Irkutsk production centers designed to supply gas to the Russian Far East and China. The contract stipulates that $38 \mathrm{bcm} / \mathrm{yr}$ will be supplied from Russia to China. Over the contract period, more than 1 -tcm gas will be supplied [25].

There are plans to add two more strings to the Nord Stream pipeline. In addition, Gazprom is also considering a $27.5 \mathrm{bcm} / \mathrm{yr}$ link for the flow of the Nord Stream gas to the

\footnotetext{
11 Russian Energy Minister Alexander Novak: Rossija mozhet vdvoeu velichit dolyu na mirovom rynke SPG [Russia might double its share in the world LNG market], 30 October 2013, available at http://top.rbc.ru/eco-
} nomics/30/10/2013/885822.shtml.
In order to guarantee its own 'security of
UK (through Amsterdam before linking up with the BBL pipeline).

A new gas pipeline project from Russia through the Black Sea to the Turkish-Greek border was offered to replace the previously envisaged South Stream pipeline partly due to the disputes with the European Commission. Also because Gazprom may have lost interest in trying to control the value chain all the way to the final consumer.

The Russian focus on pipeline gas has not prevented its ambitions in the LNG arena. Gazprom is a partner in the Sakhalin LNG, Russia's only operational LNG plant, which started operations in 2009 . About $65 \%$ of the output is delivered to Japan. Gazprom and other Sakhalin partners plan to construct a third train which will take the total capacity of the plant to $14.4 \mathrm{Mt}$ per year. Gazprom has a few other LNG plant projects; the Vladivostok LNG plant ${ }^{12}$ and Shtokman LNG plant. ${ }^{13}$ In addition, Gazprom signed a Memorandum of Understanding with the government of the Leningrad region in 2013 for the construction of a $10 \mathrm{Mt} / \mathrm{yr}$ LNG plant on its Finnish coast. ${ }^{14}$ It will not be easy to realize all these projects. Gazprom has already cancelled the Vladivostok project due to not only the concerns that the liquefaction technology might be added to the sanction list, but also that the difficulty of financing the project and finding customers [26].

There are also several LNG projects ${ }^{15}$ that are developed by the competitors of Gazprom. In April 2013, Novatek and Total have agreed, through their joint venture JSC Yamal LNG ${ }^{16}$ to build the $\$ 27$ bn Yamal LNG plant with a capacity of $16.5 \mathrm{Mt} / \mathrm{yr}$. The first train is planned to be operation in 2017, to be followed by the 2 nd and 3 rd trains of a similar capacity by 2018 and 2019, respectively. In June 2013, Novatek agreed to sell a 20\% interest in the Yamal LNG plant to the China National Petroleum Corporation (CNPC) in a framework deal that involves a long-term contract for a supply of $3 \mathrm{Mt} / \mathrm{yr}$ from the plant to China. CNPC will obtain financing for the plant from Chinese lenders [27]. In December

\footnotetext{
12 The Vladivostok-LNG project involves the construction of an LNG plant with a capacity of $10 \mathrm{Mt} / \mathrm{yr}$ expandable to $15 \mathrm{Mt} / \mathrm{yr}$ (three trains of $5 \mathrm{Mt} / \mathrm{yr}$ each) on the Lomonosov peninsula (Perevoznaya Bay). The first train is planned to begin operation in 2018. The target for LNG is Asia-Pacific markets, but Japan will probably be on the top of the list. A feasibility study has been carried out by Itochu (Japan).

13 The future of Shtokman LNG is dependent on Shtokman gas field whose development has been postponed "until better times" as Gazprom puts it.

14 The site, start date and other related information has not been provided.

15 Of these, the Pechora LNG project in the Barents Sea, sponsored by the Russian Alltech Group, seems unlikely to be realized.

16 The consortium is made up of France's Technip and Japan's JGC Corporation.
} 
2013, Novatek and Total finally approved FID on the Yamal LNG project, and according to the Gazprombank assessment report, nearly all the expected output of the LNG production has already been contracted [28]. In addition, in January 2015 Gazprom signed a 20-year contract with Novatek to offtake 2.9 Mt/yr of LNG from the Yamal LNG project [29].

Rosneft is looking to develop the Sakhalin$1 \mathrm{LNG}$ project with an initial capacity of $5 \mathrm{Mt} /$ yr. In April 2013, Rosneft and ExxonMobil agreed to investigate the possibility of building the plant to liquefy gas from their Sakhalin-1 oil and gas project. The project aims to supply LNG to the Asia-Pacific markets by 2018, which in a way threatens Gazprom's Vladivostok LNG project. In June 2013, Rosneft signed a heads of agreement with Japan's Sodeco to sell $1 \mathrm{Mt} / \mathrm{yr}$ of LNG starting from 2019 [30]. The plant is planned to be built on the Sakhalin island or in the far-eastern region of Khabarovsk. ${ }^{17}$

Some of the projects explained above may help non-Gazprom producers to exert pressure on the Russian government to break Gazprom's monopoly in the future. The first candidate is the Power of Siberia pipeline from Siberia to China. Rosneft has already threatened to take Gazprom to court if Gazprom refused to offer access to the planned capacity of $60 \mathrm{bcm} /$ year. If the pipeline will not be part of the Unified Gas Supply System, Gazprom must provide access to non-Gazprom producers [31]. So far, the pipeline is considered to be for the sole use of Gazprom; however, Rosneft and other producers have the potential to provide a substantial amount of gas into the line in the future. This goes hand in hand with non-Gazprom producers' strategy to strengthen their presence on the growing Chinese energy market. ${ }^{18}$

\section{Centralization-decentralization trends in Russia's oil and gas sectors}

Russian gas industry is in a transition process, which can be characterized by modest decentralization and more competition in the market. The evolving competitive market structure will allow non-Gazprom producers, or independents, to increase their stakes in the market. Under the auspices of the Russian Energy Policy, it will not be surprising to have a gas market that is similar to the oil market in Russia in near future. The gas sector is being transformed into a four-actor structure

\footnotetext{
17 In fact, it would have been cheaper and easier to bring Sakhalin-1 gas to the Sakhalin-2 LNG plant and install an extra train there to process it; however, for this to happen, some radical changes to the Russian gas policy are needed.

18 Rosneft has been intensively developing its oil cooperation with CNPC and Sinopec.
}

with a dominant player: Gazprom remains to be the leader, followed by a Kremlincontrolled private company Novatek, the state Oil Company Rosneft, and other companies (Lukoil, and small firms as well as international oil companies).

In contrast to the evolving structure of a competition-oriented gas market, the oil sector in Russia is changing in the reverse direction. Oil reserves and production are more and more in the hands of statecontrolled companies. In the past decade, the share of state-controlled companies (Rosneft, Gazprom Neft) in total oil production has increased to $50 \%$. The national champion Rosneft now captures the biggest share in the market, which was dominated by a fierce competition between private oil firms before.

A practical impact of the opposing centralization-decentralization trends in Russia's oil and gas sectors may lead to a further reinforcement of the national oil giant Rosneft with possible acquisition of Surgutneftegaz deal, whereas the gas monopoly Gazprom has started to lose its position both domestically and abroad. In this regard, as in the natural gas, the oil sector has also evolved into having four actors: the stateowned Rosneft (the leader), a Kremlincontrolled private company Lukoil, the subsidiary of a state gas company Gazprom Neft, and others.

The main difference between the evolving market structures in the oil and gas sectors is that in the former, the dominant state company was born from competition whereas in the gas sector, a monopolistic company has lost its power and is now expected to hold only a dominant position. Considering the high level of securitization of the Russia-European natural gas trade, in contrast to oil, this new trend may constitute grounds for the de-politicization of energy relations. For instance, decentralizations trends within Russia's gas sector can lead to a discussion of the possibility of the full liberalization of gas exports from Gazprom's monopoly.

\section{Conclusion}

With the decline in its gas production and competitiveness in the Russian gas market, Gazprom will have to adapt to the changing conditions. The effects of the major structural reforms may not be seen in the short term. However, in the longer term, the government may move to restructure Gazprom's relations with independents to prevent it from blocking strategically important projects. In the end, Gazprom might be forced to further open up its export network. This may results in the full liberalization of exports. Since the early 2013 , the issue of the liberalization of gas export has received support from the Ministry of Energy as well as
Medvedev and Putin. Liberalization has already been partly achieved for LNG exports. The target now is to break the pipeline gas export monopoly of Gazprom.

The full liberalization of access to the gas transportation system is unlikely to happen in the short term; however, the transmission segment of Gazprom may be unbundled over the long term. As the market structure of gas becomes more and more similar to that of the oil sector, like Transneft in the oil sector, a new gas transmission company can be created.

In general, there are three alternative options to reduce Gazprom's monopoly. The first is to oblige Gazprom to purchase gas produced by independent producers from fields located in the eastern part of Russia at prices calculated as a netback to export prices, and to export the gas into the foreign markets. This way, Gazprom would still remain the sole exporter and owner of the pipeline but would collect a transport fee. The second option is to encourage non-Gazprom producers to construct a gas pipeline, first to export gas to China and then to other markets. The last alternative is to create conditions for fair access to the gas network for nonGazprom producers in the Russian market and allow them to access new gas export pipelines.

It may be too early to announce the breakup of Gazprom's monopoly on transmission and gas pipeline exports but it is clear that Gazprom is facing serious challenges at home and abroad. Some dramatic shifts that are already taking place in the Russian gas sector will, sooner or later, result in the demise of Gazprom's monopoly.

\section{References}

[1] C. Locatelli, The Russian Gas Industry: Challenges to the "Gazprom Model", Cahier de recherché EDDEN n 2bis, Paris, 2013.

[2] A. Belyi, Institutional trends in Russia's oil and gas sectors, J. World Energy Law Bus. 6 (3) (2013).

[3] J. Henderson, Domestic Gas prices in Russia: towards Export netback, Oxford Institute for energy Studies (NG57), November 2011. Available from: http://www.oxfordenergy.org/wpcms/wp-content/uploads/2011/11/NG_57.pdf.

[4] Gaidar Institute for Economic Policy, Russian Economy in 2012: Trends and Outlooks (Issue 34) Moscow, 2013.

[5] M. Belova, S. Ezhov, A. Rubtsov, E. Savchik, Vygon, Gas Pricing in Russia: Searching for a Balance of Interests, Moscow School of Management Skolkovo, 2014.

[6] IEA Journal Issue: 7-2014, Market in flux: what's next for Russian Gas? (Accessed February 2015) Available from: https://www.iea.org/ieaenergy/ issue $7 /$ market-in-flux-whats-next-for-russian-gashtml.

[7] Interfax, Rosneft Signs 25-year Deal to Supply Inter RAO with Gas from 2016, 1 Nov 2012.

[8] J. Henderson, Evolution in the Russian Gas Market: the Competition for Customers, Oxford Institute for Energy Studies, 2013 (Accessed April 2014) Available from: http://www.oxfordenergy.org/ wpcms/wp-content/uploads/2013/01/NG_73.pdf. 
[9] (Accessed March2014) Available from, TSDU (Central Dispatch Administration of Fuel Energy Complex of Russia), 2014, http://www.cdu.ru/ catalog/operative_data/section.php?SECTION_ $\mathrm{ID}=119$.

[10] R. Johnston, E. Stromquist, The Russian Gas Sector: a Political Risk Case Study, James A. Baker III Institute for Public Policy of Rice University, 2014.

[11] E. Mereminskaja, Total Vipisalas v Strategiyu Timchenko, [Total Registered to Timchenko's Strategy] (Accessed December 2014) Available from, Rossiskaja Gazeta, 2011, http://www.gazeta.ru/ business/2011/03/03/3544045.shtml.

[12] Russian Ministry of Economy web-site, (Accessed January 2015) available from http://economy. gov.ru/minec/press/news/20150203102.

[13] RiaNovosti, 7 January 2014.

[14] Rosneft website, (Accessed May 2014) Available from: http://www.rosneft.com/Upstream/ GasStrategy/.

[15] IEA, Medium Term Gas Market Report - Market Trends and Projections to 2018, OECD/IEA, Paris, 2013.

[16] Energy Strategy of the Russia for the period up to 2030. (Moscow: Ministry of Energy of the Russian Federation, 2010) This official document was approved by decree no. $1715-\Gamma$ of the government of the Russian Federation on November, 2009.

[17] ERIRAS (The Energy Research Institute of the Russian Academy of Sciences), Prognoz Razvitiya
Energetiki Mira i Rossii do 2040 Goda [Prognosis of Development of World and Russian Energy to 2040], 2014 (Moscow).

[18] Central Bank of Russian Federation, 2014 (accessed June 2014) Available from: http://www.cbr.ru/ statistics/print.aspx?file=credit_statistics $/$ gas. htm.

[19] EUROGAS Market Report, March 2015, Available from: http://www.eurogas.org/uploads/media/ Eurogas_Press_Release_-_New_Eurogas_data_confirms_dynamic_EU_gas_market.pdf.

[20] European Commission, Quarterly report on european Gas markets, 1/2015, Available from: https://ec.europa.eu/energy/sites/ener/files/ documents/quarterly_report_on_european_gas markets_2014_q4.pdf.

[21] J. Stern, International gas pricing in Europe and Asia: a crisis of fundamentals, Energy Policy 64 (2013)

[22] Gazeta Vzglad, V ruki poitikov [In the hands of politicians], 2014 (Accessed May 2014), Available from: http://www.vz.ru/economy/2014/4/14/ 681974.html.

[23] Rosneft News Release, Igor Sechin Made a Report at the Presidential Commission for Fuel and Energy Industry, June 4, 2014 Available from: http:// www.rosneft.com/news/today/04062014.html.

[24] T. Mitrova, Russian LNG: the Long Road to Export, Russia/NIS center, Paris, 2013.
[25] I. Zaslavsky, Insiders benefit from Gazprom-CNPC Gas Deal, but Russia's Budget Loses, Chatham House Comments 2014, (Accessed July 2014), Available from: http://www.chathamhouse.org/ expert/comment/14633

[26] M. Bradshaw, Western Sanctions and Russia's O and Gas Challenges, ISN ETH Zurich (Accessed February 2015), Available from: http://www.isn. ethz.ch/Digital-Library/Articles/Detail/? Ing=en\&id $=186934$.

[27] Novatek company website (Accessed June 2014), Available from: http://www.novatek.ru/en/busi ness/yamal/southtambey/.

[28] Gazprombank Assesment Report for Novatek 2014 (Accessed January 2015) Available from: http:// www.gazprombank.ru/upload/iblock/a1b/gpb_ novatek_tp\%20update_040814.pdf.

[29] Gazprom Web-Site, Available from: http://www. gazprom.com/press/news/2015/january/ article213452/.

[30] The project website, Available from: http://www. sakhalin-1.com/Sakhalin/Russia-English/Upstream/default.aspx.

[31] S. Kardaś, The Creeping 'de-Gazpromisation' of Russian Exports, The Centre for Eastern Studies, 2014.

Available online 27 September 2015 